\title{
Essential Oils, Asthma, Thunderstorms, and Plant Gases: A Prospective Study of Respiratory Response to Ambient Biogenic Volatile Organic Compounds (BVOCs) [Corrigendum]
}

Gibbs JEM. J Asthma Allergy. 2020;12:169-182.

On page 172, Floral and air and thunderstorm sampling section, and on page 173, Results, Floral emissions before and after a storm section, the supplementary information link is no longer working. The updated link is http://www.dove press.com/get supplementary_file.php?f=286369.pdf.

The author apologizes for any inconvenience.

\section{Publish your work in this journal}

The Journal of Asthma and Allergy is an international, peer-reviewed open-access journal publishing original research, reports, editorials and commentaries on the following topics: Asthma; Pulmonary physiology; Asthma related clinical health; Clinical immunology and the immunological basis of disease; Pharmacological interventions and new therapies. The manuscript management system is completely online and includes a very quick and fair peer-review system, which is all easy to use. Visit http://www.dovepress.com/testimonials.php to read real quotes from published authors. 